\title{
The Miseducation of the Nigerian Architect
}

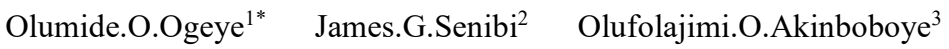 \\ 1.Department of Architecture, Dessau Institute of Architecture, Dessau, Germany. \\ 2.Department of Architecture, Covenant University, Ota, Nigeria. \\ 3.Graduate School of Architecture, University of Johannesburg, South Africa.
}

\begin{abstract}
The last century has seen design through technology alter the lives of people, from being utilized as a tool for political propaganda, to power statements, as well as improving the lives of people. Design disciplines people, and the architect who by training automatically possesses this ability becomes one of the most important people in society due to his ability to directly impact the environment. For this reason it is important to examine how his training matches up to such responsibility. However, it has been noticed that the training of the Nigerian architect hasn't developed at the rate it should, lagging behind in its use of technology, as well as the role which the architect should be playing in society. This can be traced back to his education; how he is taught, what he is taught and how he practices his profession. Education here is defined as the intentional equipping of an individual with relevant skills and knowledge which is guided towards a measurable objective. How does the training of the architect align to this? Are there really objectives and how clear are they to the lecturers and students? Are the objectives reviewed and measured for shortcomings? These fundamental questions are important in properly educating the architect. Similarly, common inhumane acts amongst some lecturers such as destruction of students' projects are some unethical acts which are questioned; are such individuals worthy of being educators, are they not unaware of their roles and what education is really about? The architect's training should be dynamic, one which must keep matching up to the new innovations and changes of our time or become a victim of it.
\end{abstract}

Keywords: Architectural Education, Miseducation, School of architecture, Architecture in Nigeria.

DOI: $10.7176 / \mathrm{ADS} / 76-08$

Publication date:September $30^{\text {th }} 2019$

\section{Introduction}

It is no news that the times which we are in now is very different from the last decade, as new innovations keep bringing new challenges which not only creates opportunities but also presents the likelihood of displacing those who are not prepared for it. The architect's training is one that is dynamic, one which must keep matching up with the new innovations and changes in the way man lives, hence it would be unfortunate if the architect who's one of the most relevant people of our time - lacks the necessary and current skills required to keep him on course. As opined by Adeyinka (1981), education should be deliberate in serving national needs; it is also an instrument of power on which national survival depends upon and this should not be taken for granted. From observation, the training of architects in Nigeria hasn't been in touch with the current realities and the changing dynamics of the Nigerian and world society; and this can be traced back to his education, how he is taught, and how he practices his profession. The architecture environment is changing; like other environments, technological advancement means that processes are being revised and modified into more efficient ways. This implies that new sets of information are becoming more relevant for the present and certain information from the past may become miseducation for tomorrow especially when it stands in the way of development. The outcome of education should be measured to analyze how effective it is in fulfilling its objective, and to examine areas that requires modification for improvement.

This paper seeks to highlight some of the educational challenges faced by the students and lecturers of architecture, and unravel the causes, and finally provide solutions to the challenges.

\subsection{Overview}

The training of the Nigerian architect is divided into two phases: the first phase lasts for 6 years (4 years for the Bachelor's degree, 2 years for the master's degree) and the second phase begins after graduation, during employment. Many who transit to the second phase experience challenges within the first couple of months as they begin to face the reality of architectural practice.

It was the norm until recently - in the last decade - to have the 6 years formal education straight without having a break in between. A reason for this was to prevent the student from losing concentration while breaking the study. Some of the earliest architecture programs in the country operated this system and this left the students with little or no choice in the possibility of following a new career path early on.

The ideology, albeit imposing may have been created in the best interest of the students, but it eventually created a great problem for the students. Many who devoted this 6 straight years of their life immediately found 
out on getting into the job market, the huge difference between the education in the classroom and the field of practice. All through the 6 years of study, they had been oblivious to the very different world that the architectural environment offered. Those who had chosen the profession for superficial reasons such as status and pride got the surprise of their lives. They soon realized that it was not as lucrative as imagined, and the big firms which were doing well thrived on projects from the state or federal government. In addition to the dilemma, it wasn't easy to get into these architectural offices, and the professional salary structure was almost nonexistent.

This shock is so strong even till today, that it immediately makes the graduate rethink his career path and take up a job in the banking sector. However how humorous it may seem, it could also be dangerous because it allows people to give up on their talents in exchange for survival. Since the architect's training is multidisciplinary it makes it possible if he wills, to take a different career path. Nevertheless, this paper focuses on the education of the Nigerian architect and this inadvertently involves all those who mentor the student in his journey to becoming an architect.

Of the many that find an alternative source of livelihood after their degree, a considerable number turn towards academia. This albeit a logical and common move has also brought some challenges in the category of lecturers and the ways in which architecture is taught. Many of these individuals are not the most passionate when it comes to teaching and thus their low motivation towards developing themselves or the student reflects in the way they teach and their willingness to constantly update themselves on changing trends in the profession (Onyegiri, et al., 2014). A lot are more conversant with theories than actual practice and this is reflected in the way students' designs are guided. Our time has seen innovation shake fundamental theories and those who are not actively and directly involved in building design and construction may keep living in a different world. This has been one of the major problems with the education of the Nigerian architect. A lot of those who are responsible for teaching and developing architecture are not in touch with the changing realities either due to null or insufficient first-hand site experience and this consequently affects the student. A teenager nurtures the dream of becoming an architect, but after passing through the system of education, his enthusiasm and creativity diminishes which makes him reconsider his dreams. This is sad but has been the reality for a long time now.

\section{Challenges}

2.1.1. Miseducation on the part of the Institution

The process of educating the architect begins from having the right teachers and also selecting the right students. The minimum criteria for being accepted to study architecture in Nigeria includes a credit in Math, English, Physics, Chemistry, Technical drawing etc., and this is expected to help in screening the students through the first stage. The second stage (the interview) however, should be one where the lecturers try to understand the thinking pattern of the student, to realize why they have chosen the path of architecture and if they are mentally prepared for the journey. Unfortunately, most universities in Nigeria admit a large number of students beyond their staff and studio capacity - rather than admitting just the right students, who based on the interview screening, indicate that they are suited and able to cope with the journey ahead.

The lecturers who take up the job of teaching architecture have also proven to be a contributing factor to the miseducation of the Nigerian Architect. The conduct displayed by most lecturers pose questions about their passion for teaching and devotion to impacting the younger generation. A common reason for this lack of motivation is the low remuneration package they receive.

The sensitivity of architectural education demands that lecturers assume the role of mentors rather than instructors. Many of the students experience disconnection with the lecturers due to the inexperience of the lecturer to deliberately understand the strength and weaknesses of their students. This dysfunctional relationship becomes apparent during jury assessments, where the student's confidence is mocked and little attention is paid to the reasoning behind their designs. Ideally, the Jury assessment should be constructive rather than destructive, and at the same time not condone laziness. In such situation, the attitude of the juror is as one who is eager for knowledge, willing to be educated by the students about the logic behind their designs. There should be a willingness on the part of the lecturer to understand the reasoning of the student and to further help in polishing the ideas of the student. This is not the case in most schools in Nigeria where the lecturers assume to have absolute knowledge and never want to be confronted. Here, the jury is like a theatre where the lecturers - who are the jurors - behave as fierce antagonists of the students. It is very common during such sessions to see students' design ideas being ridiculed unapologetically. Students tremble during these sessions because the egos of the lecturers come out to play and not wanting to bruise any ego, they find it hard to express themselves or challenge arguments being thrown at them. Ideally, the learning environment should be moulded in such a way that students are convinced that their skills, thought processes and intelligence matters, a place where healthy and constructive learning takes place between both the lecturer and student, with the quest to solve real local and global problems.

2.1.2. The teaching and learning process 
The process in which architecture is taught is very important due to its practicality. Usually the knowledge transfer in architecture comes through two sources which are, by learning and doing. Both methods are equally as important and an architect would be incomplete without the two. The first stage which often comes as learning starts sometime before the individual gets into the school of architecture. In most cases, young individuals who choose certain career paths do so due to the early influences around them, most times within the family. In such a situation the individual takes interest in the profession right from an early period and is easily attracted to architectural-related activities or TV programs. In the process of doing this, the individual's perception of architecture is being formed and developed, depending on how strong influences on him. Individuals from the upper class families who visit other countries for holidays are quickly exposed to buildings different from those in their local context, and this immediately adds to the exposure which is important for architecture. The second group of individuals are the ones with no prior knowledge of architecture, they do not have close relatives or guardians in the profession, but they think their interests and talents align with architecture and therefore believe that they can learn all about it at the university.

In the first two years of the university, students are introduced to the fundamentals of architecture such as sketching, the principles of design, etc. This period could be very challenging for students as they would need to adapt to the new demands of a higher institution of learning. The learning curve is very steep, especially as they are not properly guided the way they ought to be - like a parent who holds the hand of the child in teaching him to write. On the other hand, they learn mostly by mistakes which they are fortunate not to get away from.

The students who are already exposed to architecture rely on their rudimentary knowledge in guiding them through, while the other students basically waddle their way by either learning from their colleagues or seeking counsel from students in higher level. This is due to some of the misguided conceptions which are held by the lecturers, and one common example is the assumption that the students ought to already know certain things; an example is, knowing how the structural members within a roof is supposed to look like. This is a common exercise given to students early on and it is already expected for them to figure it out without taking them to a construction site or conducting a similar experiment to show how the roof members function. The reality is that students are taught about a practical world but are equally foreign to it and this is another major problem which the students encounter. Such assumptions by the lecturers cast the students into a world where they are compelled to know without actually knowing. On one hand, it may be seen by some as an effective way of making the student do his own research which is sometimes accounted for as hard work, but the danger it imposes could also be immense. The students simply copy their way through producing numerous drawings and details without really understanding how they function. Some lecturers being insensitive to the dangers encourage such acts, such that the student is motivated to produce for a jury exam, as many drawings of details as possible even when he can't explain them and most especially are not relevant to the design.

It is also worrying to know how common it is amongst architecture lecturers to make references to the hardship they went through as students and also expect that the young students go through the same experience. They somehow nurture the collective idea that torture and unnecessary meanness should be part of the tools in educating the student. This is not a forward way of thinking because it holds on firmly to the wrongs of the past and easily misses out on what's important for now. Inhumane acts such as tearing students' drawing because the lecturer does not like the design or outrightly cancelling drawings of students with red ink also due to prior disagreements with the design, are cruel acts exhibited within the universities. In a recent video that went viral, was a lecturer who as a way of assessing students' works during a jury session was seen flinging away the architectural models of the students - and more devastatingly -, destroying the models by walking on them as a way to show his dissent for their works. Such acts are inhumane and should be punishable because it dehumanizes and also traumatizes the students. Some lecturers deliberately frustrate the efforts of students who try to manage a master's program with a job. Rather than encourage their industriousness and zeal for learning, they intentionally mark them down on the basis of attendance even when they were forthcoming with their design submissions. This is a counterproductive way of educating especially when one realizes the motive behind it.

Debates as to whether or not the students integrate CAD with their Studio designs in the early years is still ongoing and this is baffling especially when one realizes the reasons given in opposition of the idea. Among such reasons is the belief that CAD software makes the students lazy because drawing time is optimized (Alagbe, et.al, 2014). If it took weeks to prepare a bungalow design ten or twenty years ago, it should not take as much time doing so now due to the effectiveness that time and technology affords. As a matter of fact, those who are already engaging with CAD software would disagree strongly with this point as in fact one encounters new set of challenges that arise in feeding design ideas into the computer. The masterly use of CAD software relies on the ability to understand and translate basic geometric and technical knowledge into achieving design results. Apart from it offering a high level of accuracy, early knowledge of it makes the student valuable and useful during and after their study. In Nigeria, students from their second year are expected to secure internships at architectural firms, majority of which are dependent on CAD software; but how then is the student expected to 
engage in such an office when they are discouraged from using it or even being taught at the university?

An important question that must be asked is if the 6 years of study required for the degree is actually worth it, especially when one realizes that what the students learn while working is often more relevant than what is taught in the classroom? The times have changed and 6 years of one's life devoted to obtaining a degree is a lot. With advancement in technology and access to the internet, more learning resources are easily available than before, hence learning duration could be optimized. Time and Experience have shown that it is not really in the amount of years spent, but in the content delivered and absorbed in return that counts. It is more disturbing when one realizes that the 6 years is still not a guarantee of a better livelihood. A great deal of information is imposed on the student during the years of study most of which are forgotten before the completion of their study. This should not be a surprise because what isn't put to practice is likely to be forgotten. Instead of 4 years of bachelor study, a year or one and a half out of the 4 years would be ideal for training the student through internships in architectural and design offices, such that at the end of the program, the student has a very clear understanding as well as working experience in the built environment which is not the case at the moment. This would add more value to the education of the student and would eventually strengthen the quality of candidates to be enrolled for the masters program.

\section{The way forward}

To properly educate the Nigerian architect, the educational custodians should be willing to respond to the points highlighted in this paper and cross-check it with the current situation in their respective institutions. The challenges stated above are linked to flaws from various parties involved in the process of education; however highlighted below are some loose ends to the problem, which when considered would make a great difference in the quality of education being offered.

3.1.1 Regulating bodies:

A decent approach to ensure that the architectural profession is able to stay relevant across generations will be to ensure the governing bodies have a common vision. Only when the governing body is united can they look after the interest of not only the young architects, but also those in the built environment. When this happens, then it becomes easier to speak with a unique voice in formulating an appropriate syllabus that responds not only to socio-cultural needs, but also aspires to rise with the pace of the new demands of the Nigerian society and the world at large. The current state of these bodies speaks less of true leadership, and more of misplaced priorities coated with insensitivity. The lack of true leadership can be seen in their inability to reach a consensus for the greater good of the thousands entrusted within their care. For example, to register as a professional architect requires the graduate architect to register with one of these bodies; the recent feud however has seen both bodies openly discredit the validity of the other. To therefore register with one is to alienate the other - an unhealthy foundation to build the future of the architectural profession on.

3.1.2 Teaching delivery:

A practical subject such as architecture was modelled to be taught as a practical process which involves mentorship, usually from one with a higher understanding of the complexities that exist within the profession. Here the students learn much more by absorbing what the tutor does, and employing solutions adopted by the tutors to how they challenge complexities in design (Schon, 1987). From this statement, it means that for one to be positioned as a capable mentor, it would be required that such a person has quality experience most especially from past projects where complexities were encountered and properly resolved. For the sake of clarity, complexity in this case comes from case study projects that the mentor handled in the past. Those who have spent more time on actual design projects tend to have a more advanced way of solving complexities; they know the theories that exist and have at some point had to resort to compromises in order to control the design to deliver the expected results. Overtime, these kinds of encounter builds the individual to a point where he or she becomes more enlightened than the individual that spends most of the time in the classroom.

Also, one important question that must be asked today is: who determines what materials of study are relevant for the architecture student? Is it the lecturers who spend majority of their time around the university walls trying to keep up with their career progression? Or the professionals who are so caught up in their work that they hardly think of what they can do for the future of the upcoming professionals? These two individuals are of equal importance, but both appear to move on parallel paths wherein the student lies in the middle without a clear understanding of both realities.

All of these points to the importance of teaching with practical knowledge as well as theoretical knowledge. In the words of Vitruvius, this would be theory and practice. According to Vitruvius, the architect is one that is equipped with knowledge of many branches, and this comes from a product of "theory" and "practice", simply put as "knowing" and "doing" (Morgan, 1914). Practice as he explained, is the continuous and "regular" exercise of employment where manual work is done with the necessary materials available, according to the design of a drawing. On the other hand, theory is the ability to explain the reasons behind this. He further explains that those who acquire only practical skills without theoretical knowledge never attained positions that reflected their hard 
work, while those who relied only on scholarly knowledge were hunting shadows and not the real thing (Morgan, 1914). This reveals how relying only on scholarly knowledge could affect architectural development of especially when one realizes that what is being taught is just a shadow of reality.

As a solution, schools of architecture should endeavor to employ the best breed of individuals who have experiences both in theory and practice as such individuals without doubt are more qualified in every respect to mentor students into becoming capable professionals. In a bid to attract such people, incentives should be given by the regulating bodies to the individuals that are advanced in practice in order to make themselves available to the schools to transfer their knowledge, and the schools on the other hand should endeavor to create a good environment where such collaboration could thrive easily.

3.1.3 Learning Objectives

The learning objectives within the various architectural institutions are not properly defined and measured well enough to accurately determine if the students are learning. Jury sessions and exams are the current measurement tools employed, but have not proved to be the best way of measuring what the students have learnt over time. Sometimes the hard work of the student is just enough to get good grades but does not necessarily translate to proper knowledge acquired. A better way to track the learning development of the students would be to define what ought to be learnt at each stage of their study, and the students, having a clear understanding of what they should know at the end of each stage. This way the students and lecturers can track their progress from the beginning of the study to the end. This method brings in transparency in learning, such that both sides properly appraise themselves on the status of learning at each stage. It would also discourage lecturers who focus majorly on teaching up syllabuses, caring less whether or not the students understand its content. Here, the success of the teacher is tied to the success of the students and this fosters commitment on the part of the lecturers. Likewise the advancement of the student would be dependent on his or her ability to follow through properly with the process. In addition to this, a form of assessment should be periodically conducted to test the knowledge of what the students have acquired across the different stages. By doing this, knowledge is being consolidated in the memory of the students and makes them more aware of their learning.

3.1.4 Teacher and Student relationship:

Once the above has been done, it sets the stage for the next phase which has been identified as the reorientation of the lecturers. According to popularly beliefs held by the students of architecture in Nigeria also backed by the research paper by Onyegiri and Nkemakonam (2014), architectural lecturers need to do more in regards to how they deliver their knowledge. Their role as crucibles of knowledge is often undermined, and hence the inefficiency in the transfer of knowledge. Fundamentally, a student's admittance to study indicates that the student is capable of going through the system in the chosen field of study, and under the right mentorship can finish with a minimum pass mark. However, the student's attitude to learning has a role to play, and contributes significantly to making the lecturer's job easy or impossible. The fact that this process of learning involves two parties with a common goal suggests that both parties be deliberate in meeting each other halfway.

The culture in Nigeria which creates a rigid relationship between the old and young, has contributed to the feeble relationship between the students and their lecturers. With most students capable of being fathered and mothered by their lecturers, the lecturers indirectly expect that the students give similar respect to them as the culture demands. This has its pros and cons; its pros being the ability of the student to subject themselves to the leadership of their tutors. The cons however begin to manifest when the tension between the student and lecturers are high and it impedes the cross-pollination of ideas from both parties. The learning environment should not be treated the way the cultural environment is treated although both have positive roles in the development of the Nation. The relationship between the students and lecturers should be one that nurtures the confidence of the young architects and leverages on their sense of adventure, creativity and curiosity in solving real life problems. A healthy relationship between these two parties is one that recognizes that not all students are the same, with each student bringing their strengths and weaknesses to the table to be managed and consciously developed by the lecturers for the greater good of both parties.

3.1.5 Learning Environment:

The environment in which these unique breed of students are cultured is key in determining how they would function. The environment can be referred to as the surrounding influence or external factors that contribute to the totality of the education of the student. Originally, architectural studios and offices operated within large spaces as a result of the large drawing boards needed for preparing hand drawings. With the introduction of CAD software, the sizes of offices have reduced significantly as a simple workstation cuts down the square area needed to function efficiently. This change in working style is yet to be reflected in many of the schools of architecture across the country. Reorganization of the studio setup should follow the working style of the present. Of course this would be based on whether or not the institution is willing and prepared to integrate the digitalization of architecture to their mode of teaching. This would be in the best interest of the students, as well as the teachers as it develops them into scholars of the moment who are in touch with reality. This however would mean that the lecturers be encouraged to embrace the use of technology in teaching delivery. 
There is also a need for architecture institutions to operate independently as schools rather than as small departments or part of a larger block which is the case across the country. With the current setup, the needs of the architecture departments are not adequately met (Oluwatayo, et. al, 2015). The proposed approach would make it easier to focus on the development of the students and lecturers as well as in creating better frameworks required for the specialized training of the students and lecturers. With a good understanding that not all universities in the country have the required funds to build a state of the art learning environment for its students, the onus is on the school to ensure that at the least, the facilities are decent enough to facilitate proper and efficient learning. Most importantly, the staff to student ratio should be strictly followed as it creates a stronger relationship between the students and teachers, and makes for a good learning environment.

\section{Conclusion}

The world is fast developing and the Nigerian society must be adequately equipped to solve its own challenges. The economy is predicted to experience tremendous growth and development especially in infrastructure, but if the professionals who should be at the forefront of the development are not well prepared, they could be robbed of this golden moment in time. In an interview with Arc Delano, a prominent architect from the older generation voiced the concern he and other architects within the country had for the influx of foreign architects (Njoku, 2011). Both the distinguished and non-distinguished expats have been able to charm their way into the hearts of the private and public individuals who trust in their abilities and reward them with gracious commissions. Many of these expats are tagged as illegal architects (Njoku, 2011), but this is nothing more than an appellation as it has not stopped them from smiling to the banks with the multiple contracts they keep securing. It is no news that the elite use their influence to meet their needs and this also includes commissioning architects who they desire. So the smart task should not be to strain foreign architects, but rather adequately developing the local architectural community to the point that they are adequately involved and on top of local and global discussions.

Finally, if the points which have been highlighted in this paper can be examined and further applied across the various related architectural institutions of learning, it would bring about changes in the quality of the education of the architect.

\section{References}

Adeyinka, A.A. (1981), "The Role of the Teacher in Society". Education and the Nigerian Society, Obanya, P.A.I. (Ed.), Ibadan University Press, pp. 118-133.

Alagbe, O., Aderonmu, P., Opoko, A., Oluwatayo, A. \& Dare-Abel, O. (2014), "Relevance of Manual Drafting in Design Studio Education in Nigeria: Covenant University Architecture Students' Perspective", Proceedings of EDULEARN14 Conference, 1588-1594.

Dare-Abel, O. A., Alagbe, O. A., Aderonmu, P. A., Ekhaese, O. N., Adewale, B. A. (2015). Pathways to Architectural Education and Practice Success in Nigeria. Journal of Education and Practice ISSN 22221735 (Paper) ISSN 2222-288X (Online), Vol.6, No.4, 2015.

Jolaoso, K. (2015). Architecture: A Career by Choice. International Workshop \& the African Construction Expo of the Totally Concrete, West Africa (September 1-3, 2015).

Masaruf .M, Ilyasu .M. (2016). The Architectural Education Curriculum in the Nigerian Schools of Architecture. IOSR Journal of Research \& Method in Education, ISSN: 2320-737X Volume 6, Issue 6 Ver. VIII (Nov. Dec. 2016), PP 13-17.

Njoku, J. (2011), "Why We are Against Influx of Foreign Architects - Delano", Vanguard Media Limited, Nigeria, January 04, 2011. Available online at: http://www.vanguardngr.com/2011/01/why-we-are-againstinfluxof- foreign-architects-delano/\#sthash.wpTkWcyf.dpuf

Olukanni, Aderonmu, \& Akinwumi. (2015). Pedagogic repositioning of curriculum in Architecture and Civil Engineering Education to meet indigenous needs. Edulearn Conference (p. 8). Barcelona: ISBN: 978-84606-8243-1.

Onyegiri .I\& Nkemakonam .P, (2014). The Value of Architectural Education in Nigeria: Students' Expectations in Six Schools of Architecture in South-East Nigeria. (AAE 2014 conference proceedings)

Opoko A. P., Oluwatayo A. A. (2015). Architectural Education for Today's Challenges. Arts and Design Studies, ISSN 2224-6061, Vol.38, 2015.

Schon, 1987:22 (Webster, H. (2008). Architectural education after Schön: Cracks, blurs, boundaries and beyond. Journal for Education in the Built Environment, 3(2), 63-74.)

"Vitruvius, De architectura", i.1, 1-2 (Vitruvius, The Ten Books on Architecture, translated by Morris Hicky Morgan, Cambridge, MA : Harvard University Press | London :Humphrey Milford, Oxford University Press, 1914, p. 5). 